\title{
ANÁLISE ERGONÔMICA DE OFICINA MECÂNICA DE MÁQUINAS PESADAS E EQUIPAMENTOS COMO ESTRATÉGIA DE PROSPECÇÃO DO CUIDADO EM SAÚDE DO TRABALHADOR
}

Elisangela Salvaro

Especialização em Engenharia de Segurança do Trabalho, Universidade do Extremo Sul Catarinense, eli_salvaro@hotmail.com Renata dos S. Magnus Acadêmica do Curso de Fisioterapia, Universidade do Extremo Sul Catarinense, rsm_mbh@hotmail.com

Daniela Marcelino

Acadêmica Curso de Fisioterapia, Universidade do Extremo Sul Catarinense, marcelino_daniela@hotmail.com Willians Cassiano Longen Doutor, Universidade do Extremo Sul Catarinense, willians@unesc.net

\section{RESUMO}

Em postos de trabalho da construção civil e outras áreas, a alta frequência de levantamento de pesos e a excessiva força braçal, aliada à má postura, fazem com que muitos trabalhadores tenham disfunçôes osteomusculares. Dessa forma, o intuito do trabalho foi avaliar as condiçóes ergonômicas, tendo como objetivo a adequaçáo e a melhoria da saúde, conforto, segurança e bem-estar dos trabalhadores encarregados na manutenção de máquinas pesadas, em uma 
oficina de mecânica, na cidade de Siderópolis (SC). O trabalho foi desenvolvido em um setor de manutenção mecânica, sendo este o mais crítico, devido à maior incidência de reclamaçóes. $\mathrm{O}$ setor conta com cinco trabalhadores (que foram envolvidos no estudo). Eles foram submetidos a observaçóes diretas e instrumentais por meio de registros fotográficos das condições de trabalho e atividades executadas no local. Obtiveram-se informaçóes em documentos da área de saúde e da segurança da empresa, especificamente o Laudo Técnico das Condiçóes Ambientais de Trabalho (LTCAT), Programa de Prevenção de Riscos Ambientais (PPRA) e Programa de Controle Médico de Saúde Ocupacional (PCMSO). Foi aplicado o software RULA, a fim de verificar o grau de risco ergonômico da atividade biomecânica de trabalho. Identificou-se risco ergonômico moderado (índice 5 do RULA). Entre os principais fatores negativos aos quais são expostos os trabalhadores, estão a insalubridade pelo contato com óleos, graxas e ruídos e a falta de padronizaçáo da altura das bancadas de trabalho, colaborando, assim, para o mal-estar dos trabalhadores. Uma vez que podem ocorrer afastamentos por problemas ósseo-musculares oriundos de atividades de esforço excessivo e repetitivos, observou-se que a ergonomia, por meio de levantamentos, análises, diagnósticos e recomendaçóes, deve ser a principal ferramenta a ser utilizada pelas empresas, a fim de promover a prevenção desses casos.

Palavras-chave: Ergonomia; Mecânica; Trabalho Pesado. 